\title{
The Impact of Externalities on the Innovation Activity of Russian Firms
}

\author{
Natalia Davidson \\ Associate professor, Chair of International Economics, natalya.davidson@gmail.com \\ Oleg Mariev \\ Head of the Chair of Econometrics and Statistics, o.s.mariev@urfu.ru \\ Andrey Pushkarev \\ Senior lecturer, Chair of Econometrics and Statistics, a.a.pushkarev@urfu.ru \\ Graduate School of Economics and Management, Ural Federal University, \\ 19, Mira str., Ekaterinburg 620002, Russian Federation
}

\begin{abstract}
$\mathrm{I}$

$\mathrm{n}$ this paper, we analyze the impact of externalities on firms' capacity to develop and implement innovations. We evaluate a Probit model containing both firm level factors and regional factors, such as the institutional environment, state support, and human capital. The dependent variable is a dummy variable reflecting the involvement of a firm in innovation activity. We employ data provided by BEEPS 2012-2014 for firm-level indicators and data provided by the Russian Federal State Statistics Service for region level indicators. The results confirm that at present the most important external factors affecting

the innovation activity of Russian firms are state support, both at the firm level and at the regional level, economic situation in the region, institutions, and quality of human capital. At the same time, we found several factors such as political stability, tax policy, and investment risks to be insignificant. These results require further analysis. We also found that the impact of the factors mentioned above depends on whether a region receives state support. The results imply that a differentiated policy that considers regional characteristics will probably be more effective than a uniform policy on innovation.
\end{abstract}

Keywords: innovation activity; new products; innovation policy; regional policy; competitiveness; innovation development; external factors for innovations; institutional factors; human capital; probit model

Citation: Davidson N., Mariev O., Pushkarev A. (2018) The Impact of Externalities on the Innovation Activity of Russian Firms. Foresight and STI Governance, vol. 12, no 3, pp. 62-72. DOI: 10.17323/2500-2597.2018.3.62.72 
$\mathrm{T}$ he Russian economy remains highly dependent on mining industries, which became particularly clear after the sharp decline in energy prices in 2014. Among other things, this fact is confirmed by the country's position in global innovation and business activity rankings. The most prominent of those include the European Innovation Scoreboard (EIS), the Global Innovation Index (GII), and the Global Competitiveness Index (GCI) [Vlasova et al., 2017]. Russia is present in the last two.

The leaders in the GII 2017 ranking (it covers 127 countries) are Switzerland (67.69), Sweden (63.82), and the Netherlands (63.36); Russia with its 38.76 score holds $45^{\text {th }}$ place (three points up compared with 2015). This is due, inter alia, to the fact that R\&D expenditures in the country did not fall during the 2008-2009 crisis, and though they did decrease somewhat in 2010-2012 they grew again in 2013-2015. [Dutta et al., 2017].

The GII is based on indicators reflecting the available resources and the results achieved over the course of national innovation activities. Innovation resources include institutions, human capital, research potential, infrastructure, capacity of the domestic market, and public support provided to businesses. Innovation results include technological and economic development, and the products of creative activities [Vlasova et al., 2017]. A comparative analysis of indicators achieved by the participants in the 2013-2016 rankings reveals that Russia's relatively advanced position is due to its R\&D and innovation expenditures, the level of its human capital and knowledge creation, and the advances in certain emerging technological areas, while in terms of practical application and dissemination of knowledge the country very much lags behind [Vlasova et al., 2017].

Russia traditionally has advantages regarding certain human capital-related indicators applied in this ranking, such as tertiary education and research. Institutionally, that is, in terms of the political situation, legislation, and business environment indicators, Russia's positions in the ranking have very much improved between 2013 and 2016, though the first two of these indicators do not favourably affect innovation [Vlasova et al., 2017]. In particular, these factors may lead to businesses reducing their R\&D expenditures (Figure 1), and accordingly, reduce returns of such investments compared with potential opportunities. A detailed cost-benefit analysis of innovation-related expenditures can be found in publications on the Russian context of the GII [Gokhberg, Roud, 2012, 2016].

The structure of Russian R\&D expenditures is quite different from that of the majority of developed and developing countries. For example, according to statistics, the largest share of R\&D expenditures (more than 55\%) comes from public sources, and it has increased over the years: having reached $70 \%$ in 2010 , it remained more or less unchanged since then. Meanwhile, businesses' share of the R\&D expenditures on the whole has not changed much at all, if anything, it displays a slight downward trend [HSE, 2018b]. It should be noted that during the period in question Russia pursued an active innovation policy; one of its objectives was increasing businesses' participation in funding research and innovation. In the EU and the OECD member countries, the situation is exactly the opposite: $55-65 \% \mathrm{R} \& \mathrm{D}$ expenditures are funded by companies and $25-30 \%$ by the state.

In the Global Competitiveness Index (GCI) 2015 published by the World Economic Forum for 140 countries, the top three places are held by Switzerland (5.76), Singapore (5.68), and the US (5.61). Russia is in $45^{\text {th }}$ place with a score of 4.44, up eight positions since 2014 [Schwab, 2016]. In 2016, Russia somewhat improved its position moving up from $45^{\text {th }}$ to $43^{\text {rd }}$ place, and reduced the gap with the innovation leaders for 12 out of 41 relevant indicators (for five other indicators, the country's positions deteriorated). However, this did not lead to an increase of innovation activity. In the Doing Business ranking, Russia moved up from $123^{\text {rd }}$ place in 2011 to the $51^{\text {st }}$ in 2016 [Ministry of Economic Development, 2016].

The report accompanying the GCI ranking explains Russia's progress by the high level of tertiary education and infrastructure. The authors note that in addition to the sanctions and low oil prices,

Figure 1. Structure of Russian R\&D Expenditures in 2000-2016 (\%)
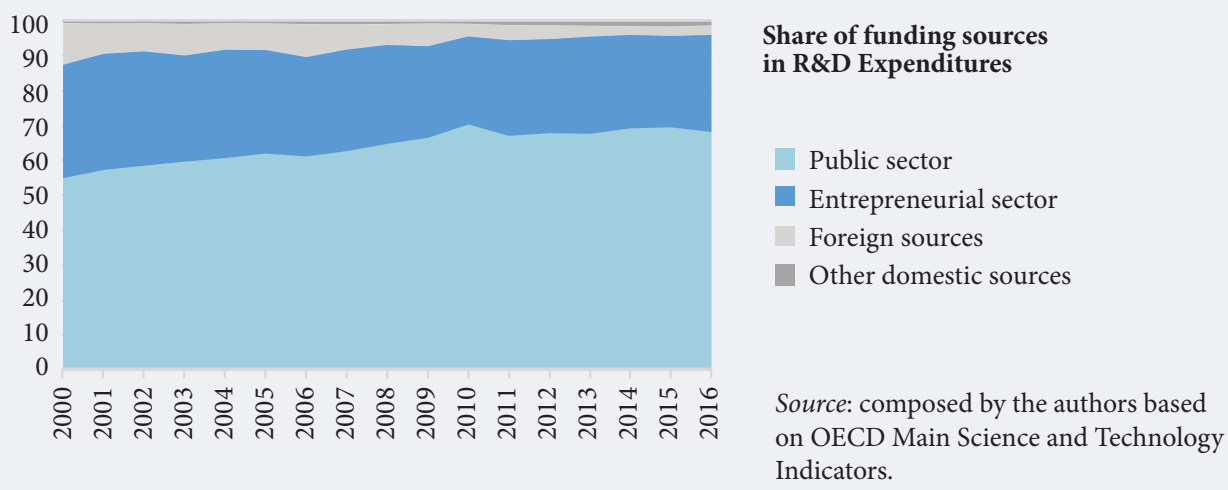
"inefficient government institutions, insufficient innovation potential, poorly developed financial markets, and lack of investors' trust in the financial system" also get in the way of Russia's increasing the number of its competitive advantages. According to members of the business community, barriers hindering development include "corruption, inefficient public administration, and high tax rates" which lead to the inefficient allocation of resources [Schwab, 2016].

A 2014 survey identified the following major barriers perceived by the private sector as hampering innovation: insufficient funding, inefficient tax policy, inadequate legislation and regulation practices, problems with securing public procurement orders, and insufficient qualifications of graduates. The second to last barrier was most frequently mentioned by small and medium entrepreneurs (58\%), and the last one - by major players (57\%) [Ministry of Economic Development, 2016]. In a survey, company managers from 140 countries including Russia were asked how well the educational systems in their countries met demand of the economy; in 2012 only $51 \%$ of the respondents said they were "at least moderately satisfied". In Russia, this share was even lower [Browne, Blanke, 2012].

In recent years the development of innovation infrastructure was seen as an important government policy area. However, numerous studies note insufficient demand for innovations in Russia, while existing demand is mainly met by imported technologies. Despite the modest number of domestic innovators, the country lacks special provisions and mechanisms for supporting companies with the potential to create world-class innovations [Ministry of Economic Development, 2016]. The interaction of various innovation and investment infrastructure facilities and division of responsibilities between them also face certain problems [Nazarov, Fomin, 2015]; as a result, these facilities are frequently used less than efficiently. In terms of the share of organizations that create technological innovations in the total number of companies, in 2016 Russia was in the second to last place among European countries, with the average industry score of $7.3 \%$, or 1.5 percentage points fewer than in 2014. The leaders in this area are Belgium (52.9\% of such organizations), Switzerland (52.7\%), and Germany (52.6\%) [HSE, 2018a].

Thus, Russian companies' innovation activities and efforts to promote them encounter certain problems that significantly limit the scope for modernizing the economy. To overcome the dependency on natural resources and alleviate the consequences of the global economic crisis, regional development priorities must be reviewed, along with improving the national innovation promotion policy [Sukhovei, Golova, 2016].

In recent years, innovation has increasingly been seen in the context of regional development, and local innovation systems. This approach focuses on factors such as regions' spatial proximity, local conditions, specific characteristics of human capital, and inter-regional cooperation. Related issues also include, among others, the smart city and smart regional specialization concepts adopted in the EU and other countries [Capello, Kroll, 2016]. Identifying factors that promote companies' innovation in the regional context becomes particularly important from this perspective.

The top places in the Russian Regional Innovation Index 2015 are taken by the Tatarstan Republic, the City of Moscow, St. Petersburg, the Nizhny Novgorod Region, the Republic of Bashkortostan, and the Kaluga Region ${ }^{1}$. Russian regions display great disparity in terms of various aspects of their innovative development and the factors affecting said development. Still, several regions have significantly improved their positions in the 2015 ranking due to better innovation policies and increased R\&D potential. Successful innovation requires coordinated action by companies, public authorities, universities, and research organizations [HSE, 2017].

Companies' innovation activities are closely connected with the long-term vision of the country's technological development. Technology Foresight studies are particularly relevant here, and the evolution of their methodologies at various stages of economic development [Gokhberg, Sokolov, 2017]. The impact of human activities on the environment, along with sustainable development objectives increase the importance of responsible research and innovation, i.e., trying to foresee and assess their possible consequences [Owen et al., 2012].

The objective of this paper is to identify factors affecting Russian companies' innovation in the scope of regional innovation systems; the results and conclusions may help increase the efficiency of local innovation activities and the interaction of their participants. Ultimately, these issues are important for economic development of individual regions and the whole country.

The next section presents a literature review. Section 3 describes the data and an econometric assessment of the factors affecting the regional innovation activities of Russian companies. Section 4 presents the results of the study, and the final section summarizes the conclusions.

\section{Literature Review}

Innovation, as an inherent component of economic activities, has always commanded the interest of researchers specializing in various areas of social and economic sciences [Solow, 1957; Arrow, 1962; Romer, 1990; Williamson, 1965; Schumpeter, 1934; etc.]. Building on the ideas presented in the classic works by

\footnotetext{
1 The index has the following components: "Socioeconomic conditions for innovation activities", "S\&T potential", "Innovation activities", and "Quality of innovation policy" [HSE, 2016].
} 
Schumpeter, present-day researchers interpret innovation as the development of new technologies, or the adoption of existing ones [Polterovich, 2017].

Innovation is indeed linked with the production of new products and services, but it is not limited to it. For example, GII reports use a broad definition of innovation initially proposed in the Guidelines for Collecting and Interpreting Innovation Data (the Oslo Manual) [OECD, Eurostat, 2005]. According to it, innovation implies the application of new or significantly improved products (goods or services), processes, marketing, or organizational techniques in the course of business practices, to organize work places or establish external relations [Dutta et al., 2017]. In terms of novelty, innovations can be divided into improvements (incremental innovations) and radical innovations with no analogues in the world [Grunwald, 2011]. A sufficiently comprehensive review of more relevant empirical studies of innovation economics can be found in [Cohen, 2010].

The issue of innovation determinants has been approached, in Russian and international literature alike, from quite different perspectives, with - unsurprisingly - very different conclusions. Let us take a look at some of the studies of external and internal factors affecting companies' innovation activities.

Many researchers analyze factors affecting companies' willingness to innovate using countries with transitional economies as examples. For example, Ljiljana Bozic and Valerija Botric [Bozic, Botric, 2011] based their study on the BEEPS data for 2009; the survey's sample included 12,000 companies in 29 countries. The applied model comprised a binary dependent variable which took the value 1 if the company implemented a new product or service during the previous three years. The results revealed that the following factors were statistically significant: subsidies, pressure by customers and foreign competition, political risks, tax rates, and various country-specific effects. In particular, the authors stressed that overcoming the shortages of skilled labor could help promote innovation.

Jana Schmutzler and Edward Lorenz [Schmutzler, Lorenz, 2015] analyzed the effect of economic activities' spatial structure on businesses' openness to new knowledge and willingness to develop new products and technologies, using data from 28 regions in seven developing Latin American countries. The authors paid particular attention to the role of regional agglomeration effects combined with the tolerance level in companies' innovation activities. Empirical data was taken from the World Values Survey (WVS) for 2005-2009 and 2010-2014. A binary dependent variable was used which took the value 1 if the company developed new or improved existing products; otherwise the variable took the value 0 . The results of the study (based on the multiple probit regression method) revealed that investing in R\&D and staff training increases the probability of companies' developing new products. Also, the authors discovered a positive correlation between the tolerance level in large agglomerations and innovative activity; companies operating predominantly in local and national markets in highly tolerant regions tended to innovate more efficiently.

Martin Srholec [Srholec, 2011] noted that innovative companies in "catch-up development" countries were primarily interested in such characteristics of the institutional environment as the business climate and stable "rules of the game" on the market. Institutional indicators applied in the logit model included, among others, the amount of time required to register a new company and settle commercial disputes; the stability of the employment index (which reflects the changes in hiring and firing rules); the level of democracy; and the highest taxation rate. The importance of most of these factors implies the need to take them into account when measuring innovation activity in Russian regions.

Martin Junge and colleagues [Junge et al., 2012] analyzed the relationship between the level of workers' education and companies' activity in the areas of product, process, organizational, and marketing innovations using an extended Cobb-Douglas function and a probit model. The Community Innovation Surveys for 2004, 2007 and 2008 were used as data sources. The authors note that an engineering education positively affects all kinds of innovation, while social sciences and humanities are particularly important for creating organizational and marketing ones. The study also established that companies creating innovations of both latter types tend to be more productive than those who are only active in one of these areas. The same applies to companies engaged in the creation of process and organizational innovations.

As to the role human capital and universities play in Russian companies' innovation, firms which cooperate with universities in order to find suitable personnel point out the low level of students' training, but on the whole were satisfied with the results of their joint research and expressed interest in using consulting services and implementing joint projects with third parties. The government is expected to apply various financial tools to promote companies' cooperation with $\mathrm{R} \& \mathrm{D}$ and educational organizations [Dezhina et al., 2017]. Universities are seen as drivers of economic growth in the scope of the "University 3.0" concept, bringing together education, research, and the commercialization of knowledge [Karpov, 2017]. In our turn, in this paper we included human capital in the number of factors important for innovation.

Foreign direct investments (FDI) remain an important innovation development factor. Their inflow is believed to promote overall economic growth, and innovation in particular, due to the spillover effects (extensively researched and described in detail in the literature), and increased competition on the market. Such mechanisms are analyzed, for example, in [Coe, Helpman, 1995; Peri, Urban, 2006].

However, more recent studies point out that the impact of FDI on domestic businesses may not be so straightforward. For example, Francisco García and co-authors [García et al., 2013] analyzed, using 
Spanish firms as an example, the mutual dynamics of FDI and innovation activities in terms of increased competition, reduced costs for all market players, and technology transfer. The authors noted that increased competition may negatively affect innovation, while the risks associated with FDI are due to the fact that the national economy becomes dependent on decisions made by foreign partners. A large FDI inflow leads to local firms being pushed into less profitable niches, which suppresses their innovation activities. The dual impact of FDI on innovation was also noted by other researchers [Fan, Hu, 2007; Girma et al., 2009; Wang, Kafouros, 2009]. In this paper we have analyzed this factor along with other regional determinants affecting companies' innovation activities.

Factors influencing companies' innovative development in specific Russian regions were studied in [Yermasova, 2014]; the author used relevant Rospatent data and investment potential and risk indices calculated by Expert Rating Agency for 83 Russian regions for 2008-2012. Dependent variables used in the empirical analysis included the number of patent applications and their registration statistics broken down by region. The study revealed a significant positive correlation between the increased innovation activity of companies in the sample on the one hand, and the volume of foreign direct investments, population density, economic risks, and capital investments on the other. Another study [Ivanova, 2010] established the $1 \%$ level of significance for key factors affecting regional innovation systems: the number of doctorate holders, R\&D personnel, and expenditures on technological innovation.

A common feature in most of the above studies is the use of corporate indicators such as productivity, revenues, $\mathrm{R} \& \mathrm{D}$ expenditures, number of personnel, etc. And though there is no doubt that they do affect companies' innovation activities, the role of the company size definitely does not seem as obvious. The larger the company is, the more opportunities it has to cut the costs through economies of scale, and the more resources it has available for long-term investments, among other things in the development of new technologies and products - i.e., ultimately, it has higher chances of ceing engaged in innovation. This conclusion is supported by empirical data published in [Berger, 2010; Grespi, Zuniga, 2012; Roper et al., 2008]. On the other hand, there are studies suggesting that small businesses can even surpass large companies in this area [Merivate, Pernias, 2006]: since they do not have comparable advantages, they frequently tend to be more perceptive to changes in the market. However, there are alternative opinions too, according to which the effect of firms' size on their innovation is not statistically significant [Klette, Kortum, 2002]. The correlation between the level of innovation and some other factors also seems to be quite complex [Mariev, Savin, 2010].

In recent years fast-growing medium-sized innovative companies have become one of the main targets of the government industrial policy. In June 2016 the Russian Ministry of Economic Development launched a project aimed at supporting leading private high-technology firms - the so-called gazelles, selected on the basis of the national TechSuccess ranking [Medovnikov et al., 2016]. A study of the ranking results for 2012-2016 revealed that the participating companies displayed a high level of uncertainty [Yusupova, Khalimova, 2017]. Particular attention was paid to the development of the national innovation system, including the reasons for its insufficient productivity in the creation, dissemination, and practical application of knowledge; the motivation of economic agents; technological externalities; and innovation-related risks [Golichenko, 2017]. The impact of national development institutes' activities on the innovative behavior of the market players was analyzed, including favorable changes in the firms' behavior following the implementation of relevant support initiatives [Simachev, Kuzyk, 2017].

Thus, we can identify the main groups of regressor indicators applied in econometric studies of innovation activity, at the national and regional levels:

1) Macroeconomic business activity indicators such as revenue, size, form of ownership, participation in import and export activities, and other cost and productivity indicators including R\&D expenditures and R\&D personnel;

2) Institutional indicators describing markets where the company operates: investment appeal, risks, taxation, entry barriers, national bureaucratic specifics, etc.;

3) Human capital indicators: labor quality, number of university graduates, companies' staff training and upgrading costs, etc.;

4) Government support indicators, typically expressed as the amount of subsidies, grants, or benefits, and accessibility of public procurement orders;

5) Other indicators including regional economic characteristics such as GRP, openness, etc.

Typically, researchers try to take into account all of the above factor groups; accordingly, we decided to include in the model presented in the next section at least one indicator from each group. This approach will allow us to assess the importance of the various indicator groups in the framework of a single model and avoid possible problems caused by the lack of potentially important variables.

\section{Input Data and Methodology}

Our study focuses on factors promoting companies' innovation. The Business Environment and Enterprise Performance Survey (BEEPS) of Russian companies conducted in 2012-2014 was used as the source of basic input data. The survey covered 4,377 organizations in 37 Russian regions; 4,167 of them 
were private companies fully under Russian jurisdiction, 146 firms were partly owned by foreign capital, and 64 companies were publicly owned. No additional limitations were applied to the BEEPS sample. The distribution of the companies by sector, size, and location is presented in Table 1 .

The information in Table 1 on the whole matches the Rosstat data. For example, according to Rosstat, wholesale and retail organizations in 2013 amounted to about $38.7 \%$ of all enterprises without account of the agriculture and mining industries ( $42.21 \%$ in the sample), and construction firms - to about $9.3 \%$ ( $10.52 \%$ in the sample). The sectoral distribution is also close to the official statistics. Therefore, we can say that in terms of industry distribution, the data is representative.

As to company sizes, the sample is biased towards medium enterprises while according to the Rosstat, small businesses make up the largest cohort. The bias is due to a number of reasons, first of all mismatched definitions, and therefore different classifications of small and medium enterprises. It cannot be ruled out that medium and large players were more willing to take part in the surveys. Correcting such a deviation from the official statistics does not seem to be possible; still, it seems to be unlikely that it have significantly affected the results of the study, because small companies' contribution to overall business activities' results at the regional and national levels is not that substantial. Also, due to specific organizational structures, financial potential, and the very nature of their activities, small companies consider implementing innovations relatively less often, and even fewer of them have the resources to carry out such projects. Therefore, the probability of the study results being significantly biased is low.

The paper is focused on external factors that affect companies' innovation; however, certain internal determinants were taken into account, too.

The hypothesis is that companies' willingness to innovate is largely determined by the external environment. Particular attention was paid to regional aspects, which were analyzed using Rosstat data on Russian regions where the surveyed companies operated.

The analysis is based on a probit model where a dummy indicator of new product or service implementation during the previous three years was used as dependent variable.

The model looks as follows:

Prob(innovation) $=\left\{\begin{array}{l}1, \text { if innov }=a X_{i j}>0 \\ 0, \text { if otherwise }\end{array}\right.$

where

Prob(innovation) is the probability of companies' innovating;

Table 1. Distribution of Respondent Companies

\begin{tabular}{|c|c|c|}
\hline Characteristics & Number of companies & Share of companies $(\%)$ \\
\hline \multicolumn{3}{|c|}{ By industry } \\
\hline Food industry & 130 & 3.08 \\
\hline Paper and paper products & 11 & 0.26 \\
\hline Textile industry & 12 & 0.28 \\
\hline Clothing & 38 & 0.90 \\
\hline Electronics & 104 & 2.46 \\
\hline Chemical industry & 125 & 2.96 \\
\hline Machinery and equipment & 129 & 3.06 \\
\hline Construction & 444 & 10.52 \\
\hline Wholesale trade & 1289 & 30.55 \\
\hline Retail trade & 467 & 11.07 \\
\hline Information and communication technologies (ICT) & 157 & 3.72 \\
\hline Other & 1314 & 31.14 \\
\hline \multicolumn{3}{|c|}{ Bysize } \\
\hline Small (<20 employees) & 1475 & 34.95 \\
\hline Medium $(20-100)$ & 2315 & 54.86 \\
\hline Large $(>100)$ & 430 & 10.19 \\
\hline \multicolumn{3}{|c|}{ By location } \\
\hline Capital city & 123 & 2.91 \\
\hline $\begin{array}{l}\text { City with a population of more than } 1 \text { million (not } \\
\text { capital) }\end{array}$ & 1077 & 25.52 \\
\hline City with a population of $250,000-1$ million. & 2586 & 61.28 \\
\hline City with a population of $50,000-250,000$ & 427 & 10.12 \\
\hline City with a population of fewer than 50,000 & 130 & 3.08 \\
\hline
\end{tabular}


Table 2. Variables Used

\begin{tabular}{|c|c|}
\hline Variable & Explanations \\
\hline Company size & $\begin{array}{l}\text { The dummy variable takes the value } 1 \text { if the company is large ( }>100 \\
\text { employees); otherwise it takes the value } 0\end{array}$ \\
\hline Competition & Number of competitors (as assessed by managers) \\
\hline Membership in a large corporate structure & $\begin{array}{l}\text { The dummy variable takes the value } 1 \text { if the company is a part of a large } \\
\text { corporation; otherwise it takes the value } 0\end{array}$ \\
\hline Subsidies & $\begin{array}{l}\text { The dummy variable takes the value } 1 \text { if the company received subsidies } \\
\text { from any sources; otherwise it takes the value } 0\end{array}$ \\
\hline Tax rates & \multirow{5}{*}{$\begin{array}{l}\text { Basic ranking of barriers in points: not present }=0 \text {; insignificant }=1 \text {; } \\
\text { moderate }=2 ; \text { main hurdle }=3 \text {; very serious }=4 \text {. The model uses binary } \\
\text { variables }[\text { Bozic, Botric, } 2011 \text { ] which take the value } 1 \text { if the relevant external } \\
\text { factor constituted the main or very serious hurdle for the company; } \\
\text { otherwise the variable takes the value } 0\end{array}$} \\
\hline Political instability & \\
\hline Corruption & \\
\hline Insufficient education level of workforce & \\
\hline Problems with access to funding & \\
\hline \multicolumn{2}{|r|}{ Regional indicators } \\
\hline Output of innovative products & \multirow[t]{2}{*}{ Logarithmic expression (2012 data) } \\
\hline FDI & \\
\hline $\begin{array}{l}\text { Share of state and municipal university graduates in the } \\
\text { total population of the region }\end{array}$ & 2012 data, $\%$ \\
\hline Investment risk associated with regions & Weight-average risk index (2012 data) \\
\hline Regions' openness & Share of foreign trade turnover in the GRP (2012 data, \%) \\
\hline Donor region (recipient) & $\begin{array}{l}\text { The dummy variable takes the value } 1 \text { if the region received grants from the } \\
\text { state; otherwise it takes the value } 0^{\star}\end{array}$ \\
\hline \multicolumn{2}{|c|}{$\begin{array}{l}\text { * Federal law “On Federal Budget for } 2014 \text { and Planning period of } 2015 \text { and 2016” № 349-FZ of 02.12.2013 (valid version of 2016) Access mode: http:// } \\
\text { www.consultant.ru/document/cons_doc_LAW_155198/, last accessed on: 25.08.2017. }\end{array}$} \\
\hline \multicolumn{2}{|c|}{ Source: calculated by the authors based on Rosstat (gks.ru) and BEEPS data [EBRD, n.d.]. } \\
\hline
\end{tabular}

$X_{i j}$ is the vector of independent variables of company $i$ and region $j$. The list of independent variables with explanations is presented in Table 2.

Table 2 shows that explanatory variables include specific characteristics of companies. We have also used indicators describing barriers hindering companies' operations, the quality of human capital, government support, and business climate in the whole country and in specific regions. In the BEEPS framework these factors are measured on the basis of the surveyed companies' managers' assessments, which provide an idea about their personal perception of the external environment for innovation.

Descriptive statistics of the model's variables are presented in Table 3. Innovative activity was measured on the basis of a binary variable which took the value 1 if the answer to the question "did the company develop new products or services" was positive; otherwise the variable took the value 0 .

The standard deviation values in Table 3 indicate significant fluctuations of the indicators. The average company size suggests that most of the surveyed firms were members of the small and medium businesses group. On average each company had four competitors; $7 \%$ of the enterprises were members of larger corporate structures.

The share of Russian firms which develop and implement new products or services amounted to almost $25 \%$ of the sample. It is slightly higher than the industry average figures for Russia mentioned in the introductory section. A possible explanation is that companies assessed their involvement in innovation themselves, so they could interpret it differently; hence the deviation from the official statistics. Even so, this indicator value is still lower than in developed European countries. The City of Moscow has the highest values of innovative products (13.11) and FDI (15.26) logarithms. The highest risk was noted in the Murmansk Region (0.361), the lowest - in the Krasnodar Region. Specific features of its geographic location explain the Kaliningrad Region's leadership in terms of regional openness (share of foreign trade turnover in the GRP). In terms of the share of university graduates in the total population, the leader is St. Petersburg.

At the initial stage, the econometric model was applied to assess the above factors' impact on companies' innovation for all regions generally. Then the differences between companies operating in "donor" and "recipient" regions were identified.

\section{Results}

The probit model described above was assessed using the maximum likelihood technique (Table 4). Since Moscow is very different from other regions in terms of the economic situation and innovation activity, companies based in the city were excluded from the econometric analysis. Apart from the model's coefficients the table also presents marginal effects showing the change of probability (in \%) of companies' 


\section{Table 3. Descriptive Statistics of the Variables}

\begin{tabular}{|c|c|c|c|c|}
\hline Variable & Mean & $\begin{array}{l}\text { Standard } \\
\text { deviation }\end{array}$ & Highest & Lowest \\
\hline $\begin{array}{l}\text { Company size (small: }<20 \text { employees, } 1 \text { point; medium: } 20-100 \text { employees, } 2 \\
\text { points; large: }>100 \text { employees, } 3 \text { points) }\end{array}$ & 1.75 & 0.62 & 3 & 1 \\
\hline Innovations (dummy variable) & 0.25 & 0.43 & 1 & 0 \\
\hline Competition: number of competitors & 3.72 & 12.08 & 100 & 0 \\
\hline $\begin{array}{l}\text { Membership in a large corporate structure (dummy variable: takes the value } 1 \\
\text { if the company is a part of a large corporation; otherwise takes the value } 0 \text { ) }\end{array}$ & 0.07 & 0.26 & 1 & 0 \\
\hline Output of innovative products & 9.87 & 1.73 & 13.11 & 5.53 \\
\hline FDI & 11.94 & 1.43 & 15.26 & 9.01 \\
\hline $\begin{array}{l}\text { Share of state and municipal university graduates in the total population of the } \\
\text { region }\end{array}$ & 0.078 & 0.027 & 0.16 & 0.03 \\
\hline Investment risk associated with regions & 0.25 & 0.05 & 0.36 & 0.17 \\
\hline Region's openness & 1.29 & 1.06 & 5.29 & 0.27 \\
\hline
\end{tabular}

engagement in innovation due to the presence or absence of the above factors. The results are provided in two formats: for all variables, and individually for significant indicators.

The results show that the larger the company is, the more inclined it is to innovate. Large enterprises typically have more opportunities to invest in $\mathrm{R} \& \mathrm{D}$, and better access to the necessary resources. The international scope of companies' activities and receiving subsidies also have a positive impact. Marginal effects in the two models indicate that, all other conditions being equal, the availability of subsidies increases the chances of companies' developing new products or services by $12-13 \%$. Since subsidies are provided for various purposes, companies may use some of them to finance innovation. Enterprises based in recipient regions also tend to show a higher willingness to innovate.

Another incentive for innovation is increased competition. Under such circumstances companies may obtain advantages by modifying, improving, or diversifying their products to distinguish them from what the competition offers - and thus promote demand for them.

Positive coefficients of indicators such as low quality of education, corruption, and limited access to funding seem to reflect the personal perception of more dire problems faced by the firms. Trying to innovate, companies encounter serious barriers, for example, a mismatch between university graduates' qualifications and the requirements of their jobs, and corruption.

There is a positive correlation between companies' implementing innovations, the overall innovation activity in the region, and the amount of FDI. By sharing their experience and technologies, enterprises can strengthen their market positions.

Table 4. Probit Model Estimation Results

\begin{tabular}{|c|c|c|c|c|}
\hline \multirow{2}{*}{$\begin{array}{l}\text { Dependent variable (probability that company } \\
\text { implemented innovations - new products or services) }\end{array}$} & \multicolumn{2}{|c|}{ (1) } & \multicolumn{2}{|c|}{ (2) } \\
\hline & $\begin{array}{c}\text { Estimated } \\
\text { coefficients }\end{array}$ & $\begin{array}{l}\text { Marginal } \\
\text { effects }\end{array}$ & $\begin{array}{c}\text { Estimated } \\
\text { coefficients }\end{array}$ & $\begin{array}{c}\text { Marginal } \\
\text { effects }\end{array}$ \\
\hline Company size & $0.14^{* * *}(0.05)$ & $0.04^{* * *}$ & $0.15^{\star * *}(0.05)$ & $0.04^{* * *}$ \\
\hline Problems with access to funding & $0.11^{\star *}(0.06)$ & $0.03^{* *}$ & $0.12^{\star * *}(0.06)$ & $0.04^{\star *}$ \\
\hline Tax rates & $-0.01(0.05)$ & -0.03 & - & - \\
\hline Political instability & $0.08^{*}(0.06)$ & 0.02 & - & - \\
\hline Corruption & $0.18^{\star * \star}(0.06)$ & $0.06^{\star \star \star}$ & $0.21^{* * *}(0.06)$ & $0.07^{\star \star \star}$ \\
\hline Insufficient education of workforce & $0.18^{\star * *}(0.06)$ & $0.06^{\star * *}$ & $0.20^{\star * *}(0.06)$ & $0.06^{\star * *}$ \\
\hline Membership in a large corporate structure & $0.14(0.09)$ & 0.05 & - & - \\
\hline Competition & $0.01^{\star * *}(0.002)$ & $0.002^{* * *}$ & $0.01^{\star \star *}(0.002)$ & $0.002^{* *}$ \\
\hline Subsidies & $0.37^{\star \star \star}(0.11)$ & $0.12^{\star * *}$ & $0.38^{\star * *}(0.11)$ & $0.13^{\star * *}$ \\
\hline Output of innovative products & $0.06^{\star \star \star}(0.02)$ & $0.03^{\star \star \star}$ & $0.09^{\star \star \star}(0.02)$ & $0.03^{\star * \star}$ \\
\hline FDI & $0.06^{\star \star \star}(0.02)$ & $0.02^{* * *}$ & $0.06^{\star * \star}(0.02)$ & $0.02^{\star \star \star}$ \\
\hline $\begin{array}{l}\text { Share of state and municipal university graduates in the } \\
\text { total population of the region }\end{array}$ & $-0.03^{\star \star \star}(0.01)$ & $-0.01^{\star *}$ & $-0.03^{\star \star \star}(0.01)$ & $-0.01^{\star * *}$ \\
\hline Investment risk associated with regions & $-0.91(0.64)$ & -0.28 & - & - \\
\hline Region's openness & $-0.1(0.07)$ & -0.03 & - & - \\
\hline Donor (recipient) regions & $0.25^{\star \star \star}(0.10)$ & $0.07^{\star * *}$ & $0.29^{\star *}(0.09)$ & $0.08^{\star * *}$ \\
\hline
\end{tabular}


Table 5. Models' Evaluation Results by Region Groups

\begin{tabular}{|c|c|c|c|c|c|c|}
\hline \multirow{2}{*}{$\begin{array}{l}\text { Dependent variable (probability that } \\
\text { company implemented innovations - new } \\
\text { products or services) }\end{array}$} & \multicolumn{2}{|c|}{ All regions } & \multicolumn{2}{|c|}{ Recipient regions } & \multicolumn{2}{|c|}{ Donor regions } \\
\hline & $\begin{array}{c}\text { Estimated } \\
\text { coefficients }\end{array}$ & $\begin{array}{c}\text { Marginal } \\
\text { effects }\end{array}$ & $\begin{array}{l}\text { Estimated } \\
\text { coefficients }\end{array}$ & $\begin{array}{c}\text { Marginal } \\
\text { effects }\end{array}$ & $\begin{array}{l}\text { Estimated } \\
\text { coefficients }\end{array}$ & $\begin{array}{c}\text { Marginal } \\
\text { effects }\end{array}$ \\
\hline Company size & $0.15^{\star \star \star}(0.05)$ & $0.04^{\star * *}$ & $0.14^{\star * \star}(0.05)$ & $0.04^{* * *}$ & $0.22(0.16)$ & 0.06 \\
\hline Problems with access to funding & $0.12^{\star * *}(0.06)$ & $0.04^{\star *}$ & $0.14^{\star \star}(0.06)$ & $0.04^{\star \star}$ & $-0.08(0.18)$ & -0.03 \\
\hline Corruption & $0.20^{\star \star \star}(0.05)$ & $0.06^{* * *}$ & $0.23^{\star * \star}(0.06)$ & $0.07^{* * *}$ & $-0.02(0.16)$ & -0.01 \\
\hline Insufficient education of workforce & $0.21^{\star * \star}(0.06)$ & $0.07^{* * *}$ & $0.14^{* *}(0.06)$ & $0.04^{* *}$ & $0.68^{* * *}(0.17)$ & $0.23^{* * *}$ \\
\hline Competition & $0.01^{\star \star \star}(0.002)$ & $0.002^{* *}$ & $0.01^{\star * \star}(0.002)$ & $0.002^{\star * \star}$ & $0.01^{\star}(0.01)$ & $0.003^{*}$ \\
\hline Subsidies & $0.38^{\star \star \star}(0.11)$ & $0.13^{* \star *}$ & $0.41^{\star * *}(0.12)$ & $0.14^{\star \star \star}$ & $0.001(0.39)$ & 0.01 \\
\hline Output of innovative products & $0.09^{\star * *}(0.02)$ & $0.03^{\star * *}$ & $0.09^{\star * *}(0.02)$ & $0.03^{* * *}$ & $2.09(19.76)$ & 0.65 \\
\hline FDI & $0.06^{\star * *}(0.02)$ & $0.02^{* * *}$ & $0.05^{\star * \star}(0.02)$ & $0.02^{\star * *}$ & $1.79(9.49)$ & 0.55 \\
\hline $\begin{array}{l}\text { Share of state and municipal university } \\
\text { graduates in the total population of the region }\end{array}$ & $-0.30^{\star *}(0.1)$ & $-0.09^{* * *}$ & $-0.38^{\star * *}(0.13)$ & $-0.11^{\star * *}$ & 0 (omitted) & 0 \\
\hline
\end{tabular}

As was noted, subsidies-related indicators play an important role in the models in question, which may be evidence of this innovation policy tool's efficiency. However, public resources are limited, especially during crises. Accordingly, the specific effects of other factors under consideration, combined with regional investments and without them, must be studied. To identify the differences, the sample of companies from 37 regions was divided into two groups - "donors" and "recipients". The results of the models' evaluations are presented in Table 5.

It was established that all of the factors in the table are very important for companies' willingness to innovate generally, and in the recipient regions particularly. The variable coefficients' signs did not change compared with the models presented in Table 5. The situation in donor regions is different: low quality of education has the biggest effect there (the marginal effect is more than five times greater than in recipient regions). The competition factor also remained important, albeit to a smaller extent.

At the same time, no statistically significant correlation between willingness to innovate and company size was found in donor regions. The insignificant effects of corruption, subsidies, and access to funding in this group of regions can be explained by the fact that companies there have fewer funding- and institutional environment-related problems. Also, one can suppose that the economic and institutional situation would be more favorable in more successful regions than in areas receiving grants and subsidies. In donor regions, the variable describing the effect of FDI on innovation activity is statistically insignificant, even though its marginal effect in this group is higher than the relevant figure for subsidized regions, and the average value for all regions in the sample alike. However, for all companies, and especially for those based in recipient regions, this variable is statistically significant. Therefore, it can be argued that attracting investments would be an efficient alternative for companies operating in that kind of region.

Our results suggest that the larger the company based in a recipient region is, the higher is its inclination to innovate. It seems that such firms have found market sustainability and adapted to the existing institutional environment. Previous research shows that in terms of the number of competitive small and medium manufacturing enterprises, Russia lags behind EU countries. Also, major players tend to be more able to invest in innovation on their own, without government support. At the same time, international experience shows that young small companies also can have significant innovation potential [Yukhanaev et al., 2015]. The above specific features of companies' innovation activities should be taken into account when implementing innovation promotion policy. The overall innovation climate in the region also plays a quite important role.

Econometric analysis shows that companies' innovation activities are hindered by corruption, inadequate financial support, and insufficient qualifications of personnel. The above issues are particularly relevant in subsidized regions, which is confirmed by the higher importance of relevant coefficients in the constructed models. Therefore, innovation policy would not be efficient without using adequate tools for fighting corruption and restructuring economic and financial institutions. The provision of subsidies and tax breaks does not relieve companies from the above problems. Keeping in mind the inadequate quality of education, particular attention should be paid to supporting universities which train highly skilled professionals specializing in priority areas, and cooperate with innovative companies. No less important would be stepping up research and extending opportunities for the cooperation of businesses, universities, and the government. Personal initiative by specific company managers, researchers, and government officials would play a crucial role here, along with the government taking steps to improve entrepreneurial climate and promote R\&D. 


\section{Conclusion}

Companies' innovation activity is linked to their long-term vision of technological development in their regions, and in the country as a whole; combined with an efficient regulation policy, innovation contributes to achieving sustainable economic growth.

An analysis of factors affecting innovation by Russian companies revealed indicators which should be taken into account while shaping federal and regional innovation policies. The availability of subsidies, level of competition, company size, and regional environment factors such as the amount of FDI and output of innovative products are the key factors affecting innovation activity. Major barriers hindering innovation include the poor quality of education, corruption, and limited access to funding. The effect of the above factors in different types of regions is not the same: in donor regions the level of competition and the quality of education have a particularly strong effect on innovation. Therefore, differentiated innovation policies which would take into account specific features of the regions could be expected to yield the best results.

Different regulation models can be applied to promote innovation, for example, subsidizing R\&D and patenting costs. More affordable alternatives can also be considered, in particular improving government policy to attract FDI. Another effective approach would be improving the competitive environment, which is confirmed by the assessment of institutional factors.

The modeling results show that corruption significantly affects the development of innovations; therefore adopting efficient tools to fight corruption and promote a favorable business climate (which hinders corrupt practices in itself) seem to be in order. It was also established that in all kinds of regions, the successful implementation of innovation potential directly depends upon the quality of human capital in the education and research spheres.

The identified factors deserve particular attention when shaping regional policies to promote the development of innovation systems. Our conclusions largely match the results of previous studies, which may be evidence of their compatibility, correctness, and certain sustainability. The experience accumulated by leading countries in the field of shaping effective innovation policies, and their relevant institutions generally can be borrowed to improve Russia's innovation policy, taking into account the disparity of its regions.

The study was supported by the Russian Foundation for Basic Research (project №18-010-01190 "Models for analysing innovation development factors and comparative advantages in the Russian economy"). The authors are grateful to Karina Nagieva, postgraduate student at the Higher School of Economics and Management of the Ural Federal University, for her contributions to this study. The authors would also like to thank participants of the conference hosted by the HSE Centre for Market Studies and Spatial Economics (St. Petersburg, June, 2016) for their valuable comments. Sole responsibility for any possible mistakes lies with the authors.

\section{References}

Arrow K. (1962) Economic welfare and the allocation of resources for invention. The Rate and Direction of Inventive Activity (ed. R.R. Nelson), Princeton, NJ: Princeton University Press.

Berger M. (2010) The innovation-productivity link - Comparing Thailand with a sample of OECD countries. Paper presented at the Fourth Conference on Micro Evidence on Innovation in Developing Economies, Tartu, Estonia, May 27-28, 2010. Available at: https://www.merit.unu.edu/meide/papers/2010/Berger.pdf, accessed 15.04.2017.

Bozic L., Botric V. (2011) Innovation Propensity in the EU Candidate Countries. Transition Studies Review, vol. 18, pp. 405-417.

Browne C., Blanke J. (2012) The Global Competitiveness Report 2012-2013, Geneva: The World Economic Forum.

Capello R., Kroll H. (2016) From theory to practice in smart specialization strategy: Emerging limits and possible future trajectories. European Planning Studies, vol. 24, no 8, pp. 1393-1406.

Coe D., Helpman E. (1995) International R\&D Spillovers. European Economic Review, vol. 39, no 5, pp. 859-887.

Cohen W.M. (2010) Fifty years of empirical studies of innovative activity and performance. Handbook of the Economics of Innovation (eds. B.H. Hall, N. Rosenberg), Amsterdam; Boston; Heidelberg: Elsevier, vol. 1, pp. 129-212.

Dezhina I.G., Medovnikov D.S., Rozmirovich S.D. (2017) Otsenki sprosa rossiiskogo srednego tekhnologicheskogo biznesa na sotrudnichestvo s vuzami [Evaluating the Demand of Russian Medium-Size Technological Companies in Cooperation with Higher Educational Institutes]. Journal of the New Economic Association, no 4 (36), pp. 81105 (in Russian).

Dutta S., Lanvin B., Wunsch-Vincent S. (eds.) (2015) The Global Innovation Index 2015: Effective Innovation Policies for Development, Fontainebleau, Ithaca, Geneva: Cornell University, INSEAD, WIPO.

Dutta S., Lanvin B., Wunsch-Vincent S. (eds.) (2017) The Global Innovation Index 2017: Innovation Feeding the World, Fontainebleau, Ithaca, Geneva: Cornell University, INSEAD, WIPO.

EBRD (n.d.) Business Environment and Enterprise Performance Survey (BEEPS). Available at: http://ebrd-beeps.com/ data/, accessed 02.08.2017. 
Ermasova N.B. (2014) Faktory, vliyayushchie na innovatsionnuyu aktivnost' organizatsii [Factors Influencing the Innovation Activity of Organizations]. Ekonomika. Upravlenie. Pravo, no 3, pp. 495-503.

Fan S.C., Hu Y. (2007) Foreign direct investment and indigenous technological efforts: Evidence from China. Economics Letters, no 96, pp. 253-258.

García F., Jin B., Salomon R. (2013) Does inward foreign direct investment improve the innovative performance of local firms? Research Policy, vol. 42, pp. 231-244.

Girma S., Gong Y., Görg H. (2009) What Determines Innovation Activity in Chinese State-owned Enterprises? The Role of Foreign Direct Investment. World Development, vol. 37, no 4, pp. 866-873.

Gokhberg L., Roud V. (2012) The Russian Federation: A New Innovation Policy for Sustainable Growth. The Global Innovation Index 2012: Stronger Innovation Linkages for Global Growth (eds. S. Dutta, B. Lanvin, S. WunschVincent), Fontainebleau, Ithaca, Geneva: Cornell University, INSEAD, WIPO, pp. 121-130.

Gokhberg L., Roud V. (2016) How to Design a National Innovation System in a Time of Global Innovation Networks: A Russian Perspective. The Global Innovation Index 2016. Winning with Global Innovation (eds. S. Dutta, B. Lanvin, S. Wunsch-Vincent), Fontainebleau, Ithaca, Geneva: Cornell University, INSEAD, WIPO. P. 159-168.

Gokhberg L., Sokolov A. (2017) Technology foresight in Russia in historical evolutionary perspective. Technological Forecasting and Social Change, vol. 119, pp. 256-267.

Golichenko O. (2017) Gosudarstvennaya politika i provaly natsional'noi innovatsionnoi sistemy [Public policy and national innovation system failures]. Voprosy Ekonomiki, no 2, pp. 97-108 (in Russian).

Grespi G., Zuniga P. (2012) Innovation and Productivity: Evidence from Six Latin America Countries. World Development, vol. 40, no 2, pp. 273-290.

Grunwald A. (2011) Responsible Innovation: Bringing together Technology Assessment, Applied Ethics, and STS Research. Enterprise and Work Innovation Studies, vol. 7, pp. 9-31.

Hall B.H., Rosenberg N. (2010) Chapter 1. Introduction to the Handbook. Handbook of the Economics of Innovation (eds. B.H. Hall, N. Rosenberg), Amsterdam, Boston, Heidelberg: Elsevier, vol. 1, pp. 3-9.

HSE (2017) Reiting innovatsionnogo razvitiya sub"ektov Rossiiskoi Federatsii [Russian Regional Innovation Scoreboard], issue 5 (ed. L.M. Gokhberg), Moscow: HSE (in Russian).

HSE (2018) Indikatory innovatsionnoi deyatel'nosti 2018 [Indicators of Innovation in Russian Federation 2018], Moscow: HSE (in Russian).

Ivanova O.P. (2010) Formirovanie innovatsionnoi regional'noi sredy kak determinanty povysheniya konkurentosposobnosti predpriyatij [Formation of an Innovative Regional Environment as Determinants of Enhancing Enterprise Competitiveness]. Problemy sovremennoi ekonomiki [Problems of Modern Economics], no 2, pp. 47-55 (in Russian).

Junge M., Severgnini B., Srensen A. (2012) Evidence on the Impact of Education on Innovation and Productivity (Copenhagen Business School Working Paper 2-2012), Copenhagen: Copenhagen Business School. Available at: http://openarchive.cbs.dk/bitstream/handle/10398/8498/Junge_Severgnini_S\%C3\%B8rensen.pdf?sequence=1, accessed 14.06.2018.

Karpov A. (2017) Sovremennyi universitet kak draiver ekonomicheskogo rosta: modeli i missii [Modern university as an economic growth driver: Models \& missions]. Voprosy Ekonomiki, no 3, pp. 58-76.

Klette T.J., Kortum S. (2002) Innovating Firms and Aggregate In-novation. Journal of Political Economy, vol. 112, no 5, pp. 986-1018.

Mariev O.S., Savin I.V. (2010) Faktory innovatsionnoi aktivnosti rossiiskikh regionov: modelirovanie i empiricheskii analiz [Factors of innovation activity of Russian regions: Modeling and empirical analysis]. Ekonomika regiona, no 3, pp. 235-244 (in Russian).

Medovnikov D., Oganesyan T., Rozmirovich S. (2016) Kandidaty v chempiony: srednie bystrorastushchie kompanii i programmy ikh podderzhki [Candidates for champions: Medium-sized fast-growing companies and programs for their support]. Voprosy Ekonomiki, no 9, pp. 50-66 (in Russian).

Merivate E.J., Pernias J.C. (2006) Innovation complementarity and scale of production. Journal of Industrial Economics, vol. 54, no 1, pp. 1-30.

Ministry of Economic Development (2016) Natsional'nyi doklad ob innovatsiyakh v Rossii [National report on innovations in Russia], Moscow: RF Ministry of Economic Development (in Russian). Available at: https://www. rvc.ru/upload/RVK_innovation_2016_v.pdf, accessed 06.08.2018.

Mokyr J. (2010) The contribution of economic history to the study of innovation and technical change: 1750-1914. Handbook of the Economics of Innovation (eds. B.H. Hall, N. Rosenberg), Amsterdam, Boston, Heidelberg: Elsevier, vol. 1, pp. 12-50.

Nazarov M.A., Fomin E.P. (2015) Problemy razvitiya innovatsionnoi infrastruktury v rossiiskoi ehkonomike [Features of innovation infrastructure development in Russian economy]. Ekonomicheskie nauki [Economic Sciences], no 4 (125), pp. 38-43 (in Russian).

OECD, Eurostat (2005) Oslo Manual. The measurement of scientific and technological activities. Proposed guidelines for collecting and interpreting technological innovation data, Paris: OECD; Eurostat.

Owen R., Macnaghten P.M., Stilgoe J. (2012) Responsible Research and Innovation: From Science in Society to Science for Society, with Society. Science and Public Policy, vol. 39, no 6, pp. 751-760. DOI:10.1093/scipol/scs093.

Peri G., Urban D. (2006) Catching-up to foreign technology? Evidence on the "Veblen-Gerschenkron" effect of foreign investments. Regional Science and Urban Economics, vol. 36, pp. 72-98. 
Polterovich V.M. (2017) Teoriya endogennogo ekonomicheskogo rosta i uravneniya matematicheskoi fiziki [The Theory of Endogenous Economic Growth and Equations of Mathematical Physics]. Journal of the New Economic Association, no 2 (34), pp. 193-201 (in Russian).

Romer P.M. (1990) Endogenous technological change. Journal of Political Economy, vol. 98, no 5, pt. 2, pp. 71-102.

Roper S., Du J., Love J. (2008) Modelling the innovation value chain. Research Policy, vol. 37, no 6-7, pp. 961-977.

Schmutzler J., Lorenz E. (2015) Tolerance, agglomeration and enterprise innovation performance: A multi-level analysis of Latin American regions. Gredeg, vol. 43, pp. 1-30.

Schumpeter J.A. (1934) The Theory of Economic Development, Boston, MA: Harvard University Press.

Schwab K. (2016) The Global Competitiveness Report 2015-2016, Geneva: The World Economic Forum.

Simachev Yu., Kuzyk M. (2017) Vliyanie gosudarstvennykh institutov razvitiya na innovatsionnoe povedenie firm: kachestvennye effekty [The impact of state development institutions on the innovative behavior of firms: Qualitative effects]. Voprosy Ekonomiki, no 2, pp. 109-135 (in Russian).

Sokolov A., Chulok A. (2014) Russian S\&T Foresight 2030: Identifying new drivers of growth, Brussels: European Commission. Available at: https://ec.europa.eu/jrc/sites/jrcsh/files/fta2014-t1Practice_177.pdf, accessed 21.04.2018.

Solow R. (1957) Technical change and the aggregate production function. Review of Economics and Statistics, vol. 39, pp. 312-320

Srholec M. (2011) A multilevel analysis of innovation in developing countries. Industrial and Corporate Change, vol. 20, no 6, pp. 1539-1569.

Sukhovei A.F., Golova I.M. (2016) Obosnovanie transformatsii prioritetov nauchno-tekhnologicheskogo razvitiya regionov RF v usloviyakh global'nogo krizisa [Substantiation of the transformation of the priorities of scientific and technological development of the regions of the Russian Federation in the conditions of the global crisis]. Ekonomika regiona, vol. 12, no 3, pp. 911-923 (in Russian).

Vlasova V., Kuznetsova T., Roud V. (2017) Analiz draiverov i ogranichenii razvitiya Rossii na osnove informatsii Global'nogo innovatsionnogo indeksa [Drivers and limitations of Russia's development based on the evidence provided by the Global Innovation Index]. Voprosy Ekonomiki, no 8, pp. 24-41 (in Russian).

Wang C., Kafouros M.I. (2009) What factors determine innovation performance in emerging economies? Evidence from China. International Business Review, vol. 18, no 6, pp. 606-616.

Williamson O.E. (1965) Innovation and market structure. Journal of Political Economy, vol. 73, pp. 67-73.

Yukhanaev A., Fallon G., Baranchenko Y., Anisimova A. (2015) An investigation into the formal institutional constraints that restrict entrepreneurship and SME growth in Russia. Journal of East-West Business, vol. 21, no 4, pp. 313-341.

Yusupova A., Halimova S. (2017) Kharakteristiki, osobennosti razvitiya, regional'nye i otraslevye determinanty vysokotekhnologichnogo biznesa v Rossii [Characteristics, features of development, regional and sectoral determinants of high-tech business in Russia]. Voprosy Ekonomiki, no 12, pp. 142-154 (in Russian). 